\title{
Public-private partnership as an innovative approach for sustainable tourism in Guanacaste, Costa Rica
}

\author{
María Dolores Herrero Amo \\ ESCP Europe-Madrid Campus, Madrid, Spain, and \\ M. Cristina De Stefano \\ ETSII, Universidad Politécnica de Madrid, Madrid, Spain
}

\begin{abstract}
Purpose The current tourism model based on luxury hotel resorts in the Gulf of Papagayo (Guanacaste, Costa Rica) is largely affecting the living condition of its nearby communities. This paper aims to discuss the importance of promoting public private partnerships (PPPs) as innovative forms of governance to increase the sustainability of this tourism model.
\end{abstract}

Design/methodology/approach Based on the review of institutional documents and the PPP literature, this article critically maps each stage of the process to design PPPs for sustainable tourism, taking into account the case of Guanacaste. In this way, it offers a practical guideline to plan partnerships involving academia, public institutions and private partners in particular tourism sites.

Findings The paper shows that the feasibility of a PPP in Guanacaste strongly depends on the alignment of partners' local interests, on the adequacy of the partnership to the social and economic conditions of the context wherein it has to be carried out, and on the appropriation of results from partners.

Originality/value This work combines a theoretical and practical perspective to understand the interactive process to be carried out to design PPPs in developing tourism destinations.

Keywords Innovation, Tourism, Sustainability, Costa Rica, Central America, Public private partnership (PPP)

Paper type Viewpoint

\section{Introduction}

Tourism associated with beaches, protected areas and other natural resources often produces serious environmental and social problems. Hotels, cruise ships and transportation operations, along with roads and other supporting infrastructure, not only generate pollution but also destroy and degrade the biodiversity habitat (Blackman et al., 2014), affecting seriously the social and economic welfare of host communities (Gómez-Nieves, 2014). Nowadays, this hard reality characterizes the Gulf of Papagayo in Guanacaste. It is one of the most luxurious and exclusive tourism sites in Costa Rica with a tourism model based on more than 15 luxury hotel resorts (ICT, 2014). Over the last 15 years, however, this tourism model has been the main cause of environmental damage and social struggle with no improvement in the extreme socioeconomic conditions of local communities. Indeed, Guanacaste is still one of the least-well developed regions in Costa Rica (MIDEPLAN, 2017).

The aim of this study is to discuss how a public-private partnership (PPP) can be a suitable tool to promote sustainable tourism by reducing the gap between the seriously 
deprived socio-economic conditions of the local population and the wealth generated by luxury tourism. Research has largely assessed how to promote sustainable tourism (Matarrita-Cascante et al., 2010) and even highlighted the importance of partnerships between private and public stakeholders (Wilson et al., 2009). However, studies about partnerships for sustainable tourism are still scarce (Albrecht, 2013) and, they almost completely neglect the analysis of the process of partnership development in developing countries.

Drawing on these gaps, this study contributes to the literature by discussing the early stages that characterize the formulation of a PPP for sustainable tourism in developing countries. By combining an "on-site” experience and Glasbergen's (2011) framework, this work offers an applied perspective to building a PPP for sustainable tourism, stressing all challenges and difficulties that characterize each stage of that building process. This approach offers a starting point for reflection on what sustainable tourism really is about, offering useful guidelines for proposing future PPPs to be implemented in communities similar to the one in Guanacaste.

\section{The tourism model and the socio-economic and environmental conditions in Guanacaste}

In the 60s and 70s, Culebra Bay (also known as the Gulf of Papagayo), in the north of Guanacaste (Costa Rica), was selected as the main location for resort and residential-based tourism. The Gulf of Papagayo project (hereafter referred to as the Papagayo project) has its origins in the Central American development strategy to promote international tourism based on the European model. It was the only tourism investment of the Costa Rica government carried out with the participation of the ICT (Costa Rican Tourism Institute). The project, however, did not take-off until the late of 1990s, and it became more significant after 2002, due to political instability in the region, a lack of governmental experience and resources and failure in attracting foreign investments (Honey et al., 2010).

Although the Papagayo project approach has not been adopted elsewhere in Costa Rica, it has played a critical role in creating the climate for residential and resort development along much of the Pacific coast. Between approximately 2002 and 2008, the Guanacaste region became the epicenter of tourism development. In late 2003, after the Four Seasons resort opened, the Papagayo project quickly helped attract luxury category tourists and other five-star hotels such as RIU, Paradisus Conchal and JW Marriot (Honey et al., 2010; Nacion, 2011). The main hotel developments are located near the beaches Hermosa, Ocotal, Flamingo, Brasilito, Conchal and Tamarindo, as well as in some protected areas. All these sites became the main tourism destination of Guanacaste (Estado de la Nación, 1999).

From the early hotel buildings, the Papagayo project was, however, characterized by errors and controversies due to corruption, environmental and labor law violations and damage to archeological sites. The project was supposed to generate employment for thousands of local people. However, in 2008, only about 1,400 jobs were produced in the region (Honey et al., 2010). In 2010, Guanacaste had an unemployment rate of 9.6 per cent versus 7.3 per cent for the rest of the country (Nacion, 2011). Further, the unemployment rate increased during 2013 and 2014 (MIDEPLAN, 2017). Additionally, the total poverty index of 32.6 per cent in 2010 paradoxically increased to 33.2 per cent in 2014 (PNUD-Costa-Rica, 2014). Furthermore, workers suffered from conditions that reflect inequality: Every day, in Guanacaste, Nicaraguan migrants worked to build luxury hotels, villas and apartment complexes while they struggled with inadequate living conditions and no work visa (Martínez, 2009). 
The development of large hotel resorts has also been characterized by an uncontrolled building plan, which has greatly affected the natural resources of the region. Some hotels such as Allegro Papagayo, Occidental Grand Papagayo and Giardini di Papagayo were closed in 2007 and 2008 because of the illegal discharge of sewage into the ocean. Black water, solid waste, water pollution and deforestation penalized the rural activities of the local community and this led to social struggles (Hernández and Picón, 2013; BiamonteCastro, 2014). The Guanacaste population also suffered from the negative effects of tourism in terms of scarce access to some beaches and potable water, due to the massive consumption of these resources by hotels and other tourism facilities (Canales, 2012). The unsustainability of the Papagayo project was evident in 2009 during the economic crisis. In those years, the national geographic journal indicated a fall of two points in terms of Costa Rica's sustainable destination status.

Given these realities, this study suggests that the promotion of PPPs for sustainable development can be a suitable tool to focus the government and industry's attention on more sustainable tourism policies in Guanacaste. In particular, PPPs for sustainable tourism emerge as a part of the "corporatist model" (Moore and Weiler, 2009) where the public and the private sector work together to provide a service to society (Wilson et al., 2009). In this way, PPPs for sustainable tourism are legitimated by the positive effects that can be generated by communities (Morrison et al., 2004).

\section{Public-private partnerships for sustainable development}

PPPs for sustainable development were debated at the 2002 World Summit on Sustainable Development (WSSD) conference in Johannesburg (South Africa). In WSSD, PPPs are recognized as a decisive tool in achieving global sustainability (Hens and Nath, 2003; Eweje, 2007). These are collaborative arrangements among different actors such as governments, international organizations, private corporations and civil society (Van Huijstee $e$ t al., 2007), which share common objectives, responsibilities, risks, benefits and investments in a nonhierarchical way. Here, all partners are viewed as equal, with the same level of power (Hale, 2004; Bäckstrand, 2006; Cañeque, 2007; Pattberg et al., 2012).

Since PPPs can involve different types of actors, the literature has also defined them as multi stakeholders or cross-sector partnerships (Selsky and Parker, 2005; Bäckstrand, 2006; Bitzer et al., 2008; Morsink et al., 2011) and as innovative forms of governance to address sustainability (Samii et al., 2002; Pattberg et al., 2012). Most scholars consider PPPs as a shift from the traditional perspective, according to which the responsibility for dealing with sustainability issues is exclusively attributed to governmental organizations, to a new institutional arrangement where other spheres or sectors of society are called to collaborate (Streck, 2004).

In line with this last perspective, PPPs are also considered to be a potentially effective response to the failure of governance in dealing with sustainability problems (Schaferhoff et al., 2009). Indeed, the management and the solution of sustainability problems involve complexities that exceeds the capacity and expertise of a single actor, and requires collaboration with other entities representing different sectors of society (Van Huijstee et al., 2007). The cooperation among different entities can therefore address multiple challenges related to sustainable development such as economic growth, education, health care, poverty alleviation, community capacity-building and environmental sustainability (Selsky and Parker, 2005). Additionally, PPPs can be an effective way to focus global resources on certain local environmental goals, shifting the scale of sustainable development activities from a broad commitment to a specific project (Hale, 2004). This specificity can result in a greater likelihood of adopting concrete and tailored actions, taking into account the primary 
problems of a particular local reality. Nowadays, citizens are more results-oriented demanding, critical and active in requiring local governments to improve their ability to manage services effectively and efficiently. The diffusion of PPPs can therefore be a strategy to open up the process of decision-making to local stakeholders that increasingly demand a greater participation in decisions concerning the territory in which they live (Bisceglia and Leda, 2013).

\section{A proposed PPP for sustainable tourism in Guanacaste}

An important issue in the study of PPPs is to understand their design. According to Glasbergen (2011), PPPs "differ from other partnerships in intensity, scale intention and activity and, understanding their development process can help to ensure long-term sustainability and success". The objective of this study is to discuss some critical issues that arise in designing PPPs for sustainable tourism in Guanacaste by referring to the first three scales (internal interactions) of the partnership activity proposed by Glasbergen (2011): building trust, the creation of collaborative advantages and the construction of a rule system. The paper reports on a real experience of a PPP proposal in Guanacaste, which involved the Technical Office for Development Cooperation (OTC) of the Spanish International Cooperation Agency for Development (AECID)[1] of Costa Rica (as a public partner), the ESCP Europe (as an academic partner), and the RIU hotel resort (as a private partner) (hereafter referred to as the OCT-ESCP-RIU project).

\section{Building trust}

According to Glasbergen (2011), a first activity in the process of PPP development is to promote collaborative and constructive interactions between potential partners in order to create an atmosphere of mutual trust. Mutual trust does not arise spontaneously but it needs to be managed. Some conditions to facilitate it are to produce a minimal structure and ground rules to provide security, equity and fairness to the partners. Mutual trust can be achieved if all parties involved in the partnership perceive the opportunity to secure value from it.

In the OCT-ESCP-RIU project, the activity of building trust was based on several interactive dialogs between partners aimed at developing and designing a PPP that was aligned with the political priorities of the Costa Rican Government and with the real needs of the hotel resort and the nearby communities. These interactions were oriented to secure consensus about a shared vision of the PPP project and to identify the appropriate context in which to intervene. A shared vision between partners was met by establishing the following common objectives of the PPP project. A first objective consisted of designing and implementing diagnostic methodologies in the hotel to assess the social, environmental and economic impact of its activity on the nearby community. A second objective referred to the development of an action plan to test a good, practical approach to securing a positive impact by the hotel on the nearby communities.

The above objectives were formulated on the basis of the principles of alignment and harmonization of the Paris Declaration on Aid Effectiveness. On the one hand, the alignment principles of the 2013-2016 AECID Fourth Director Plan, contemplated explicitly the importance of developing a business orientation towards learning and knowledge and the need to involve the private sector in the activities of development. One of the horizontal programs developed regionally to implement 2013-2016 AECID Fourth Director Plan strategies, was ARAUCLIMA, a program to tackle climate change and promote sustainable development. ARAUCLIMA provided both technical and financial support to selecting projects that contribute effectively to knowledge management, institutional strengthening 
and articulation of the actors and instruments of Spanish Cooperation. On the other hand, the harmonization principles guaranteed that the PPP's objectives were aligned with the Costa Rican public policies whose objective was to contribute directly to the 2015-2018 Costa Rican National Development Plan (NDP). In particular, the OCT-ESCP-RIU partnership expected to contribute to the development of the following areas: competitiveness, social welfare, natural environment, as well as to some aspects of the Costa Rican program "Weaving Development" defined by Costa Rica National Authorities (see Table I).

Following the harmonization principles of the Paris Declaration on Aid Effectiveness, logically structured in the sequence: Plan - Program - Project (Robinson et al., 1993), the Gulf of Papagayo tourism site, in Guanacaste region was also identified as the priority geographical area in which to intervene. In this region, the development of traditional "sun and beach" tourism had contributed to a re-start of the agribusiness economy hitherto stagnant, but it had not improved the social and economic conditions of the nearby communities. Nevertheless, between 2011 and 2014, the Ministry of Tourism and ICT (Costa Rican Tourism Institute) continued to define and implement administrative policies, rules and regulations in favor of the hotel business for promotion of the development of the Gulf of Papagayo. Policies exclusively based on granting concessions to hotels only contributed to consolidation of the existing tourism model, with no enhancement of the socio-economic conditions of the nearby communities (Moya, 2014).

The literature indicates that the evolution of the tourism model in Central America has been characterized by three models:

- a "segregated" tourism model, dominated by foreign multinationals;

- a "relative integration" model that integrates the segregated model with the population and local entrepreneurship; and

- an "integrated" model, managed by local small and medium enterprises, wherein community interests prevail (Cordero, 2006).

\begin{tabular}{|c|c|c|c|}
\hline $\begin{array}{l}\text { Principles for aid } \\
\text { effectiveness }\end{array}$ & Plan & Program & $\begin{array}{l}\text { PPP project objectives } \\
\text { shared by all partners }\end{array}$ \\
\hline Alignment & $\begin{array}{l}\text { AECID Fourth Director } \\
\text { Plan (2013 2016) } \\
\text { Involve private business } \\
\text { sector in activities of } \\
\text { development. Increase the } \\
\text { orientation of business } \\
\text { toward learning and } \\
\text { knowledge as } \\
\text { performance }\end{array}$ & $\begin{array}{l}\text { ARAUCLIMA } \\
\text { Knowledge management, } \\
\text { institutional } \\
\text { strengthening and } \\
\text { articulation of actors and } \\
\text { instruments of Spanish } \\
\text { Cooperation }\end{array}$ & $\begin{array}{l}\text { Scope } 1 \\
\text { Design and implement } \\
\text { methodologies (operational } \\
\text { tools) to evaluate the social, } \\
\text { environmental and economic } \\
\text { impact of a private hotel resort } \\
\text { on the nearby communities } \\
\text { (Diagnostic stage) }\end{array}$ \\
\hline Harmonization & $\begin{array}{l}\text { Costa Rican National } \\
\text { Development Plan } \\
\text { (2015 18) } \\
\text { Science technology and } \\
\text { innovation, cooperation, } \\
\text { strengthening civil } \\
\text { society, the environment } \\
\text { and climate change. } \\
\text { Guanacaste as a priority } \\
\text { geographical area }\end{array}$ & $\begin{array}{l}\text { "Weaving Development" } \\
\text { Improve competitiveness, } \\
\text { social welfare and natural } \\
\text { environment (protection } \\
\text { and conservation) }\end{array}$ & $\begin{array}{l}\text { Scope } 2 \\
\text { Develop an action plan to test } \\
\text { a good practice enables to } \\
\text { promote a positive impact of } \\
\text { hotel resort on the nearby } \\
\text { communities }\end{array}$ \\
\hline
\end{tabular}


In the Gulf of Papagayo, the tourism model development has been predominantly segregated, with a strong presence of foreign multinational companies and the building of large hotel resorts located in luxury tourism sites (Cordero, 2006). The identification of this context to apply the defined methodologies was the determining factor in the process for achieving a partners' common vision. This is because, the final objective of the OCT-ESCPRIU project was to try to move the current segregated tourism model of Guanacaste towards a relatively integrated tourism model.

With this purpose in mind, another key aspect that led partners to build mutual trust was the development of an early idea about potential practices to implement for increasing the positive impact of hotel activities on the nearby community. The idea was settled in the first exploratory meeting by the managers of the hotel, the OTC Costa Rica project technicians and an expert of the University of Earth (a local university specializing in sustainable agronomy). It drew on examples from other experiences developed in other areas of the North of Costa Rica: La Fortuna and Monteverde in Puntarenas. Specifically, La Fortuna offered a model of inclusive tourism where the local population (through small and mediumsized companies) developed their own business by selling tourism products and services.

\section{Collaborative advantages}

In terms of building trust there are the collaborative advantages that partners can capitalize on partnerships (Glasbergen, 2011). Although partners can explore how they can work together and find common ground for action, a partnership is a contractual arrangement where partners have to obtain advantages and share risks. Collaborative advantages may consist of the acquisition of resources, skills, relationships or consent and, concretely, arise when partners connect their own interest with the common objectives of the partnership. If partners are driven to collaborate by different motivations, and face different benefits and risks, a sense of unfairness can erode partners' trust (Glasbergen, 2011).

Motivations and collaborative advantages are however interdependent. The reasons that lead a partner to participate in a partnership tend to promote collaborative advantages. In the OTC-ESCP-RIU project, from the beginning of the project formulation, the motivations to participate in the partnership legitimated the position of each partner in it. Specifically, OTC Costa Rica would benefit from the specific know-how developed in the PPP project as well as from the capacity, co-financing and the technical support of the other partners to achieve the priorities of the Costa Rican public policies. Furthermore, the implementation of a PPP in Guanacaste would have allowed it to standardize a working practice for future projects.

For RIU Hotels and Resorts, the main motivation was to implement its Corporate Social Responsibility strategy by participating in the partnership. So far, RIU's "sustainability policy" had consisted of taking action to meet the sustainability certification as required by the ICT. These certifications primarily benefit the hotel's processes and procedures. RIU, therefore, did not standardized a concrete action plan for promoting actions directed to involve the local community in relation to social and environmental sustainability. Through the partnership, RIU would have had the opportunity to develop a more complete/holistic sustainability approach for its core business, basing it not only on the legislative model of the ICT, but also on the possibilities for contributing actively to the corporate social responsibility of the hotel value chain. Additionally, its presence in a PPP would have contributed to differentiating its product/service - thereby increasing its competitive advantage in Guanacaste.

Finally, ESCP Europe, as an academic partner with its team of experts, brought their experience in the design, implementation and evaluation of projects and initiatives to the 
area of sustainable tourism. Their particular interest was to increase their knowledge in this field. Involvement in a PPP would have offered the opportunity to have direct contact with the business and an opportunity to test methodologies developed theoretically.

\section{Constitution of a role of system}

A third activity of the internal interaction of the partnership process according to Glasbergen's (2011) framework is the role of a system. This comprises internal aspects, which define the mutual obligations of partners, and external aspects, which are related to how the partnership will interact with other organizations. The formalization of these aspects requires different transactional and procedural elements, such as commitments, different tasks and resources, and how the partnership will deal with decision-making processes, monitoring and enforcement (Glasbergen, 2011).

The role of the system for the OTC-ESCP-RIU project was to operate as a consortium of institutions that, linked to a common goal, put their capabilities at the service of the whole partnership, sharing responsibilities and assuming risks and achievements. In particular, the mutual obligations and the specific contributions and roles of partners were the following:

- OTC Costa Rica, as a public partner, worked as a facilitator of the PPP by proposing an action-oriented system and tracking plan that the parties could adopt to achieve the expected results. Besides, OTC Costa Rica monitored and supported all stages of the PPP project implementation.

- RIU Hotels and Resorts, as a private partner, contributed to the validation and improvement of the methodology for impact analysis. The role of the hotel resort was functional to replicate the use of the developed methodologies in other hotels of the same chain as well as in other, similar contexts, i.e. in hotels and hotel chains operating in countries characterized by not inclusive socio-economic realities.

- ESCP Europe, as an academic partner, contributed to the design of the diagnostic methodologies and collect data/criteria in order to assess the social, economic and environmental impact of the hotels' activities on the nearby communities.

Once identified, the partners' obligations/commitments were encapsulated in a memorandum of understanding that detailed how the decision-process structure would be established. It consisted of working procedures and the monitoring and internal communication required for effective coordination between the stakeholders. The decisionprocess structure identified two main phases and a related timeline:

(1) Phase 1: (diagnosis and definition of the action plan-Months 1-2): collection of data about the activities currently carried out in the hotel and identification of the activities that could improve the economic, social and environmental impact of the hotel in the nearby community.

(2) Phase 2: (execution and implementation of the action plan - Months 3-13): implementation of the defined action plan, that included:

- the definition of a system oriented to monitor the results of the project;

- identification of the target community;

- awareness and training defined in the diagnosis of the local farmers, cooperative work with artisans; and

- launch and implementation of the initiative.

These phases were coordinated by partners via monthly meetings. 


\section{Conclusions}

In an effort to map the interactive internal process of the partnership activities according to Glasbergen's (2011) framework, an important aspect that emerges from this study is that a PPP for sustainable tourism in Guanacaste (Costa Rica) is viable when the partners' interest are aligned. The alignment of all interests involved in the partnership can enable a common vision as to how all partners can contribute to solving a given problem. Second, the PPP project has to be adequate to the context wherein it will be implemented. The adequacy of the project helps to secure the necessary resources for its implementation. Finally, the attainment of real advantages from the partnership helps to ensure effective collaboration between partners.

This study contributes in three ways to the literature. First, it offers a tangible example of PPP in the area of sustainable tourism - rarely analyzed at ground level - so far. Studies on PPPs are limited and often focused on protected areas. This study emphasizes the synergies that can arise among local governmental institutions, industry and academia. In particular, it highlights the role of academia in a PPP sometimes disputed in the literature (Lehmann, 2008). A second contribution of this paper is to shed light on the early internal interaction processes of a PPP and its key role in ensuring the startup and success of the partnership. Finally, this study is focused on Central America and it is only quite recently that analysis has occurred in this region. This is a helpful counter-balance to the many PPPs that have been implemented in the Northern hemisphere, wherein political, economic and social conditions are completely different.

\section{Note}

1. AECID: Agencia Española de Cooperación Internacional para el Desarrollo (Spanish Agency for International Development Cooperation).

\section{References}

Albrecht, J.N. (2013), "Networking for sustainable tourism towards a research agenda", Journal of Sustainable Tourism, Vol. 21 No. 5, pp. 639657.

Bäckstrand, K. (2006), "Multi stakeholder partnerships for sustainable development", European Environment, Vol. 306, pp. 290 306, available at: https://sustainabledevelopment.un.org/content/ documents/1312HLPF Brief 3.pdf

Biamonte Castro, G. (2014), "Estrategia de desarollo rural y turismo sustentable en Costa Rica', turismo sustentable y desarollo rural”, Estudios en Polonia, Costa Rica y México, pp. 4658.

Bisceglia, R. and Leda, I.L.S. (2013), Alianza Público Privada Resultados de la Investigación Sobre Enfoques y Experiencias, available at: www.ilsleda.org/usr files/documents/fydem 1 alianza publico privada social 940277.pdf

Bitzer, V., Francken, M. and Glasbergen, P. (2008), "Intersectoral partnerships for a sustainable coffee chain: really addressing sustainability or just picking (coffee) cherries?”, Global Environmental Change, Vol. 18 No. 2, pp. 271 284, doi: 10.1016/j.gloenvcha.2008.01.002.

Blackman, A. Rica, C. Ange, A., Naranjo, L., Robalino, J., Alpi, F., Rica, C., Rivera, J. and Rica, C. (2014), "Does tourism Eco Certification pay? Costa Rica' s blue flag program", Vol. 58, pp. 4152 , doi: 10.1016/j.worlddev.2013.12.002.

Canales, D. (2012), "Guanacaste: más turistas, más pobreza", LaRepublica, available at: www. larepublica.net/noticia/guanacaste mas turistas mas pobreza

Cañeque, F.C. (2007), Alianzas Público Privadas Para el Desarrollo, available at: www.fundacioncarolina. es/wp content/uploads/2014/08/DT9.pdf 
Cordero, U.A. (2006), Nuevos Ejes de Acumulación y Naturaleza: el Caso Del Turismo. Consejo Latinoamericano de Ciencias Sociales, CLACSO, Buenos Aires.

Estado de la Nación (1999), Capitulo 6: Los Desafios de la Región Chorotega, Estado de la Nación, available at: www.estadonacion.or.cr/files/biblioteca virtual/006/I CAPTUL6.PDF

Eweje, G. (2007), "Strategic partnerships between MNEs and civil society: the post WSSD perspectives”, Sustainable Development, Vol. 15 No. 1, pp. 1527.

Glasbergen, P. (2011), "Understanding partnerships for sustainable development analytically: the ladder of partnership activity as a methodological tool", Environmental Policy and Governance, Vol. 21 No. 1, pp. 1 13, doi: 10.1002/eet.545.

Gómez Nieves, S. (2014), "Problemas y desafío del turismoalternativo en México. Similitudes y diferencias con Costa Rica", Turismo sustentable y desarollo rural. Estudios en Polonia, Costa Rica y México.

Hale, T.N. (2004), "Thinking globally and acting locally: can the Johannesburg partnerships coordinate action on sustainable development?", The Journal of Environment and Development, Vol. 13 No. 3, pp. 220 239, doi: 10.1177/1070496504268699.

Hens, L. and Nath, B. (2003), "The Johannesburg conference", Environment, Development and Sustainability, Vol. 5 Nos 1/2, pp. 739.

Hernández, A. and Picón, J. (2013), "Huella hídrica en tierras secas: el caso del turismo de sol y playa en Guanacaste (Costa Rica)", Revista de Ciencias Ambientales, Vol. 45 No. 1, pp. 4150.

Honey, M., Vargas, E. and Durham, W.H. (2010), Impacto Del Turismo Relacionado Con el Desarrollo en la Costa Pacifica de Costa Rica, available at: http://biologia.ucr.ac.cr/profesores/Garcia \%20Jaime/ TURISMO/DESARROLLO \%20COSTA \%20PACIFICA \%20DE \%20CR IMPACTO INFORME 2010.pdf

ICT (2014), "Informe final de gestión", Compendio de los logros más importantes del Ministro de Turismo en el período 20112014.

Lehmann, M. (2008), "Conceptual developments and; capacity building in environmental networks: towards public private academic partnerships for sustainable development", available at: http:// vbn.aau.dk/ws/files/16475857/Dissertation final070408.pdf

Martínez, L.C. (2009), "Guanacaste construye su riqueza con miles de manos pobres”, 13 January, pp. 15.

Matarrita Cascante, D., Brennan, M.A. and Luloff, A.E. (2010), "Community agency and sustainable tourism development: the case of La Fortuna, Costa Rica", Journal of Sustainable Tourism, Vol. 18 No. 6, pp. 735 756, doi: 10.1080/09669581003653526.

MIDEPLAN (2017), "Estadisticas regionales 2010 2015”, available at: https://documentos.mideplan.go. cr/alfresco/d/d/workspace/SpacesStore/15588f8a da77 46ba b0b9 b51f2c130b49/Costa Rica Estadisticas Regionales 2010 2015.pdf?guest true

Moore, S.a. and Weiler, B. (2009), "Tourism protected area partnerships: stoking the fires of innovation", Journal of Sustainable Tourism, Vol. 17 No. 2, pp. 129 132, doi: 10.1080/ 09669580802582506.

Morrison, A., Lynch, P., Johns, N., Morrison, A., Lynch, P. and Johns, N. (2004), "International tourism networks", International Journal of Contemporary Hospitality Management, Vol. 16 No. 3, pp. 197 202, doi: 10.1108/09596110410531195.

Morsink, K., Hofman, P.S. and Lovett, J.C. (2011), "Multi stakeholder partnerships for transfer of environmentally soundtechnologies", Energy Policy, Vol. 39 No. 1, pp. 15, doi: 10.1016/j. enpol.2010.09.043.

Moya, A.F. (2014), "Informe final de gestión", available at: www.visitcostarica.com/ict/pdf/ Informe Final de Gestion 2011 2014.pdf

Nacion (2011), "Riqueza guanacasteca aún no baña a sus pobladores", 25 July, available at: www. nacion.com/archivo/riqueza guanacasteca aun no bana a sus pobladores/LZTEJT3SYFHKPJM LIIFGXCHZDA/story/ 
Pattberg, P., Biermann, F., Chan, S. and Mert, A. (2012), "Introduction: partnerships for sustainable Development”, in Pattberg, P., Biermann, F., Chan, S. and Mert, A. (Eds), Public Private Partnership for Sustainable Development, Edward Elgar Publishing Limited.

PNUD Costa Rica (2014), Reducir la Pobreza en Costa Rica es Posible Propuestas Para la Acción I 2014.

Robinson, N.A., Astorga, L.E., Oksanen, T., Trigo, E.J., Pastora, O., Pastor, P. and Ruiz, M.P. (1993), Agenda 21: Earth's Action Plan (No. GTZ 798), Gland (Suiza).

Samii, R., Wassenhove, L.U.K.N.V.A.N. and Bhattacharya, S. (2002), "An innovative public private partnership: new approach to development”, World Development, Vol. 30 No. 6, pp. 9911008.

Schaferhoff, M., Campe, S. and Kaan, C. (2009), "Transnational Public Private partnerships in international relations: making sense of concepts, research frameworks, and results", International Studies Review, Vol. 11, pp. 451474.

Selsky, J.W. and Parker, B. (2005), "Cross Sector partnerships to address social issues: challenges to theory and practice", Journal of Management, Vol. 31 No. 6, pp. 849 873, doi: 10.1177/ 0149206305279601.

Streck, C. (2004), "New partnerships in global environmental policy: the clean development mechanism", The Journal of Environment and Development, Vol. 13 No. 3, pp. 295322 , doi: $10.1177 / 1070496504268696$.

Van Huijstee, M.M., Francken, M. and Current, L.P. (2007), "Partnerships for sustainable development: a review of literature", Environmental Sciences, Vol. 4 No. 2, pp. 7589.

Wilson, E., Nielsen, N. and Buultjens, J. (2009), "From lessees to partners: exploring tourism public private partnerships within the New South Wales national parks and wildlife service", Journal of Sustainable Tourism, Vol. 17 No. 2, pp. 269 285, doi: 10.1080/09669580802495774.

\section{Corresponding author}

M. Cristina De Stefano can be contacted at: mcristina.destefano@upm.es 